\title{
Buried fluvial incisions as a record of Middle-Late Miocene eustasy fall on the Armorican Shelf (Bay of Biscay, France)
}

\author{
Fabien Paquet ${ }^{\mathrm{a}, \mathrm{e}, *}$, David Menier $^{\mathrm{a}}$, Guilhem Estournès ${ }^{\mathrm{a}}$, Jean-François Bourillet ${ }^{\mathrm{b}}$, \\ Pascal Leroy ${ }^{\mathrm{c}}$, François Guillocheau ${ }^{\mathrm{d}}$ \\ a Université de Bretagne-Sud, EA 2219 GeoArchitecture, Campus de Tohannic - ENSIbs, rue Yves Mainguy, 56017 Vannes, France \\ b IFREMER, Centre de Brest, 29280 Plouzané, France \\ ' IUEM, Technopôle Brest-Plouzané, 29280 Plouzané, France \\ d Université de Rennes 1, UMR-CNRS 6118 Géosciences Rennes, Campus de Beaulieu, CS 74205, F-35042 Rennes Cedex, France \\ e BRGM, Geology Division - Geology of Sedimentary Basins, 3 rue Guillemin, BP 36009, 45060 Orléans Cedex 2, France
}

\section{A R T I C L E I N F O}

\section{Article history:}

Received 12 February 2009

Received in revised form 3 November 2009

Accepted 7 November 2009

Available online 16 December 2009

Communicated by D.J.W. Piper

\section{Keywords:}

Armorican Shelf

incised valleys

Miocene

eustasy

passive margin

\begin{abstract}
A B S T R A C T
High-resolution seismic data have been acquired in June 2008 on the Armorican Shelf (AS), in the northern Bay of Biscay, in order to reassess its stratigraphic architecture in detail and to study the impact of eustasy, tectonic and sediment delivery on the margin sedimentary record. Several profiles show fluvial-type incisions of several tens of meters (up to $54 \mathrm{~m}$ ) associated to a widespread erosion surface. Several hypotheses are proposed for the stratigraphic position of this surface and incisions. We suggest Middle to Late Miocene age. Considering the relatively quiescent tectonic activity of the margin, we infer that the relative sea-level fall responsible of aerial incision on the Miocene shelf is eustasy-related. We propose the attested Serravallian-Tortonian eustatic lowstand (c. 11.6 Ma) as the key event responsible of such erosion and incision. This event marks the early beginning of the high-amplitude sea-level fluctuations that culminated during the Pleistocene and significantly controlled the present day AS morphology. The variability of vertical incision observed along single reaches can be explained by the confluence of several tributaries, the sinuosity of the channel and can be amplified by the unconsolidated nature of the Miocene substratum. The main pathways of the fluvial network corresponding to these buried valleys have been reconstructed and connections to other existing networks are proposed.
\end{abstract}

(c) 2009 Elsevier B.V. All rights reserved.

\section{Introduction}

In low sedimentation rate and quiescent passive margins, eustasy has a predominant effect on the stratigraphic architecture (Vail et al., 1977; Posamentier and Vail, 1988). In such settings, the development of fluvial channel incisions over the shelf is considered as an indicator of a significant global sea-level fall and lowstand, that expose the entire shelf below or close to the breakpoint (Dalrymple et al., 1994) and is associated sometimes to submarine canyon incisions (Vail et al., 1991). Several examples are documented worldwide and are used to date or constrain the amplitude and effects of eustasy changes through time (Fulthorpe et al., 1999, 2000; Lofi and Berné, 2008) or are the subject of ongoing studies (e.g. IODP expeditions 313 and 317). In the northern Bay of Biscay, numerous Quaternary incised valleys described over the Armorican Shelf illustrate the impact of the high-amplitude Pleistocene glacio-eustasy falls (c. $-120 \mathrm{~m}$ ) (Pinot, 1974; Menier et al., 2006; Chaumillon et al., 2008). Important sealevel falls of several tens of meters are also suspected for the Neogene

\footnotetext{
* Tel.: + 332386447 51; fax: + 33238643333 .

E-mail address: f.paquet@brgm.fr (F. Paquet).
}

period (Haq et al., 1987) and may have resulted in the generation of a fluvial networks over the emerged AS. Despite the presence of widespread erosion surfaces, related Neogene channel incisions are not attested and clearly described directly offshore southern Brittany. This is mainly due to the scarcity and the average quality of data (Bourillet et al., 2005). However, the "Quaternary" network drawn by Pinot (1974) was partly based on the detection of incisions on seismic data, c. $100 \mathrm{~km}$ from the present day coastline. Surprisingly, the Pleistocene valley network as described in recent studies (Menier, 2004; Menier et al., 2006; Thinon et al., 2008) does not extend that far over the outer shelf. A re-evaluation of the stratigraphic position of the outer-shelf incisions of Pinot (1974) was therefore needed to verify a pre-Quaternary age attribution. Evidence of potential Neogene channel incisions in surrounding areas is located in the Western Approaches and are associated with the 'Fleuve Manche' paleoriver system (Reynaud et al., 1999; Bourillet et al., 2006) where Neogene series are well-documented (Evans and Hughes, 1984), and to the South, over both the Vendean-Armorican Platform (Huerta et al., 2010) and the North Aquitaine shelf (Bellec et al., 2009).

This study presents the interpretation of recent high-resolution seismic sparker profiles acquired on the Armorican Shelf that show 
clear incisions within the Miocene series. We discuss the origin and the age of these incised valleys, and describe their morphology and potential significance in terms of eustasy.

\section{Geological setting}

The Armorican Shelf (AS) corresponds to a segment of the European Atlantic margin in the northern Bay of Biscay (Fig. 1). Its formation initiated during the Early Cretaceous (Barremian-Aptian, c. $125 \mathrm{Ma}$ ) consequently to the rotation of the Iberian Peninsula and the contemporaneous opening of the Bay of Biscay (Montadert et al., 1979; Olivet, 1996; Thinon, 1999). Its present day morphology corresponds to a large polygenetic erosion surface (wave-planed) resulting from significant Plio-Pleistocene sea-level fluctuations (Imbrie et al., 1984; Waelbroeck et al., 2002). The Cenozoic was dominated by postrift mixed carbonaceous-silicoclastic sedimentation as revealed by exploration well PENMA-1 (Preux, 1978), and cores (Bouysse et al., 1974; Thomas, 1999; Guillocheau et al., 2003). The knowledge of the stratigraphic architecture of the AS is provided by interpretation of seismic data from the Bir Hakeim survey (Bouysse et al., 1968) and correlations with PENMA-1 well (Guillocheau et al., 2003). Post-rift deformation occurred mostly in response to the Pyrenean collision that reactivated strike-slip Variscan structures (Montadert et al., 1979). This subsequent Oligocene compressive phase did not affect obviously this area such as it did in the English Channel, with the modification of the Hurd deep (Lericolais et al., 2003). The limited Cenozoic tectonic activity in the study area is evidenced by subvertical faults that suggest a dextral strike-slip movement that faded during the Miocene (Figs. 4 and 5). The margin is also affected by an apparent seaward regional tilt documented onshore (Bonnet et al., 2000) and offshore (Vanney et al., 1972; Bourillet et al., 2003). Several regional erosion surfaces resulting from sea-level changes
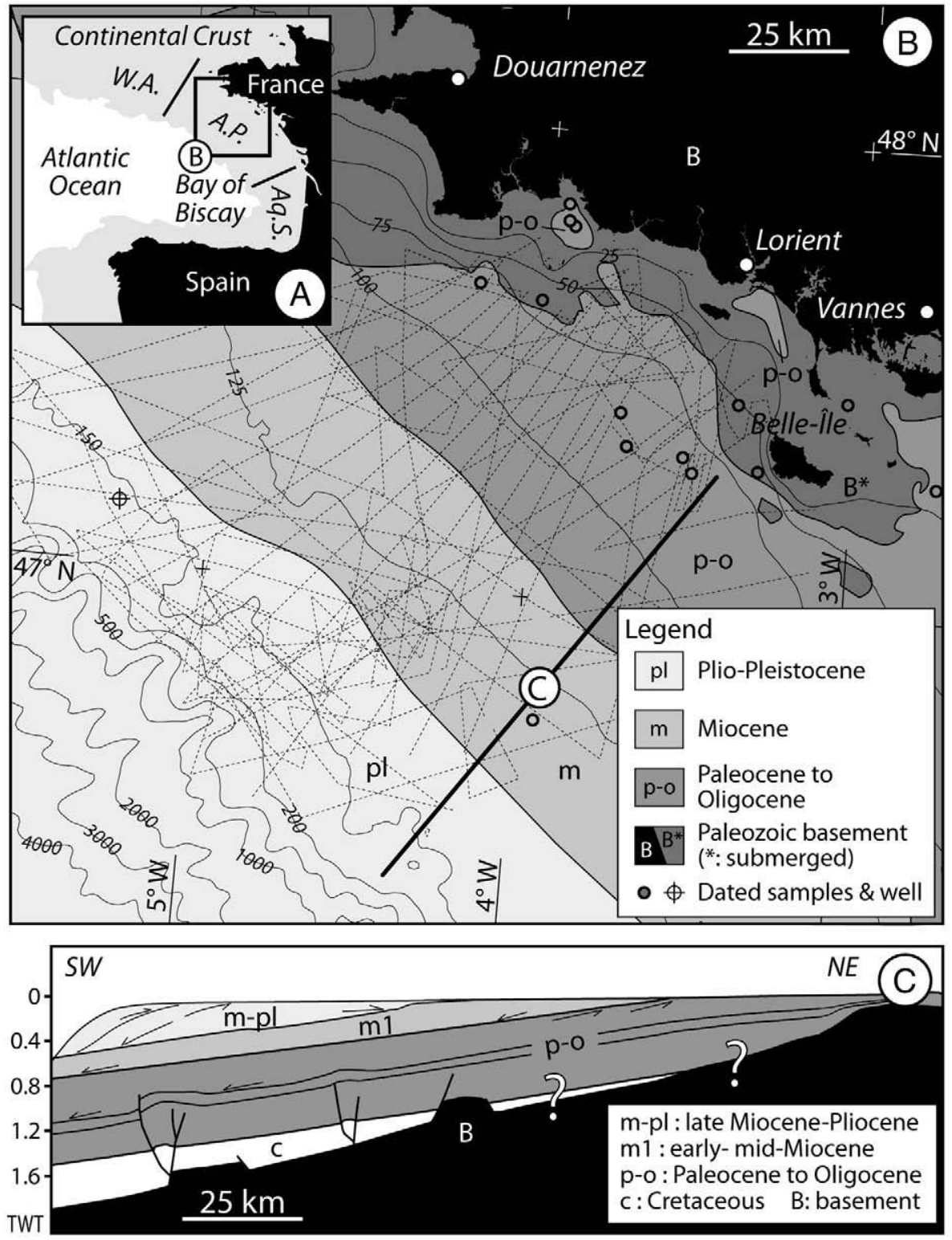

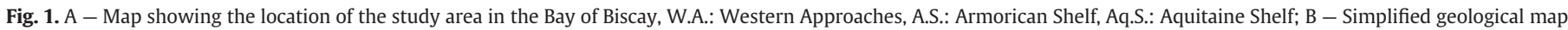

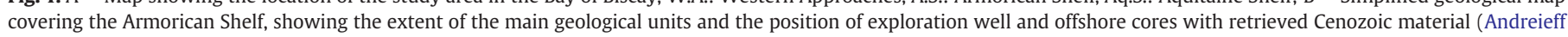

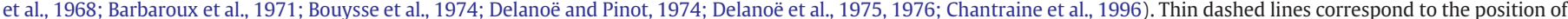

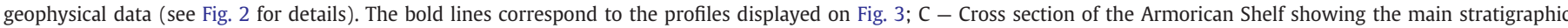

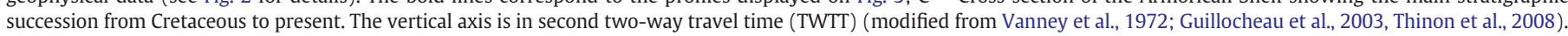
See (B) for location. 


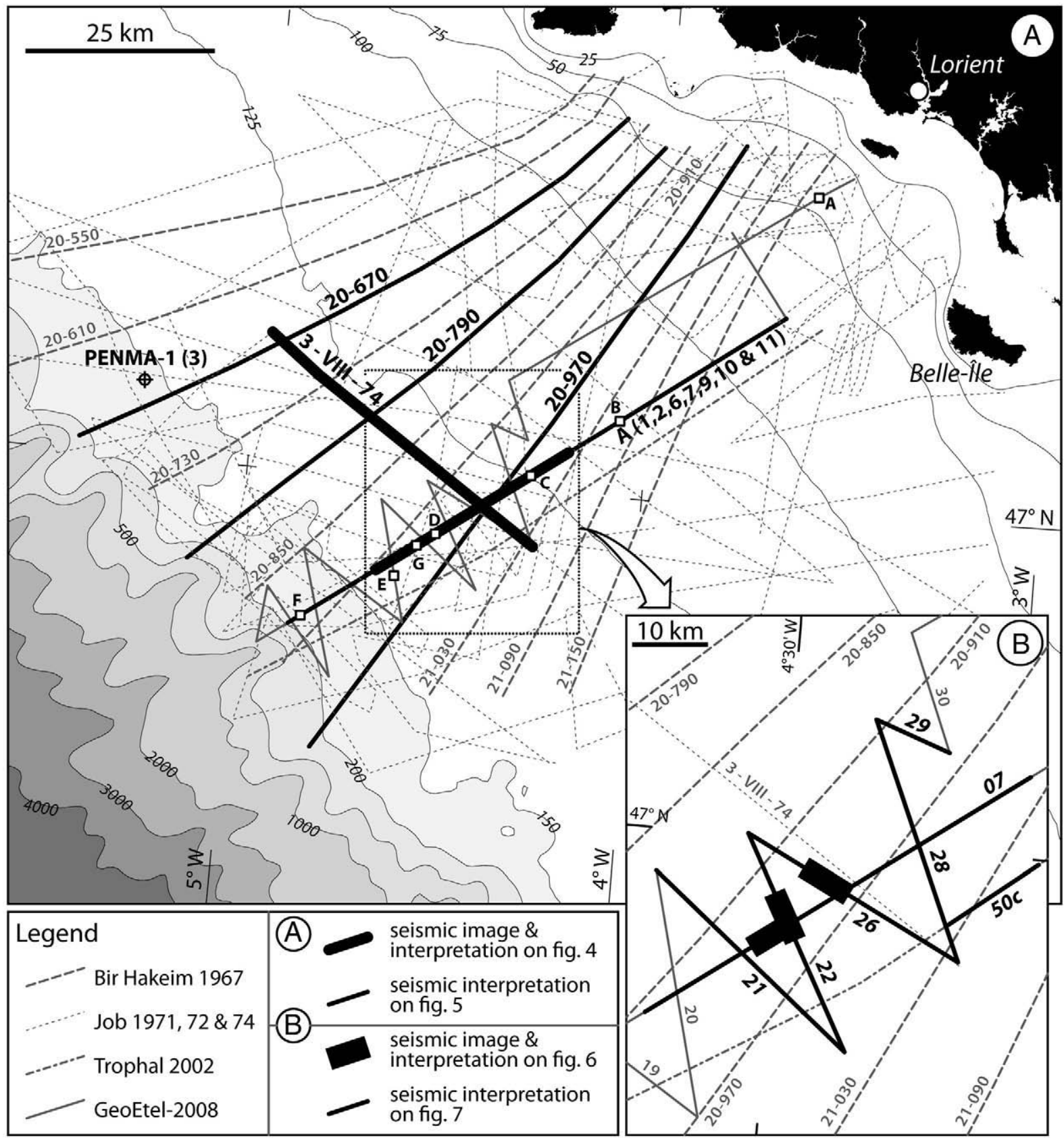

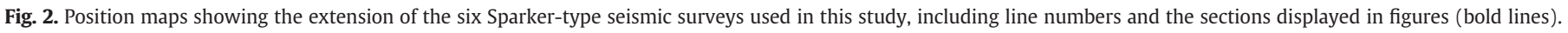

and/or phases of regional tilt are recorded and form angular unconformities (Figs. 1C, 4 and 5). One of these surfaces is interpreted to be Middle to Late Miocene in age (Vanney et al., 1972; Guillocheau et al., 2003; Bourillet et al., 2003). The Miocenerecent deposits of the AS margin are mostly located on the median and outer parts of the shelf where they form a stack of wedges (Figs. 1C and 5). Incised valleys are present over the inner shelf and the coastal area (Boillot et al., 1971; Bouysse et al., 1974; Menier, 2004; Menier et al., 2006; Chaumillon et al., 2008). The origin of both these incisions and their valley fills is linked to Late Pleistocene sea-level fluctuations. Unfortunately, due to coarse superficial sediments, no attempts at coring have yet succeeded in recovering paleovalley fill (Bourillet and Turon, 2003).

Recently acquired high-resolution seismic data detail the geometry of the sedimentary succession and associated erosion surfaces.
One of these surfaces revealed several incisions, c. $100 \mathrm{~km}$ from the present day coastline.

\section{Methodology}

This study is based on the interpretation of high-resolution Sparker seismic data acquired onboard CNRS-INSU "Côtes de la Manche" vessel in June 2008 (GeoEtel-2008 survey,) as well as the re-interpretation of lower-resolution seismic profiles from older surveys onboard Bir Hakeim vessel in 1967 and Job-ha-Zelian vessel (Job) in 1971, 1972 and 1974. Seismic units and bounding surfaces are defined by describing reflection continuity, amplitude, frequency, configuration and terminations (Mitchum et al., 1977). The seismic stratigraphy obtained from our interpretations have been geometrically correlated to cores and dredges samples and to PENMA-1 exploration well, which 
provides the only regional access to the Meso-Cenozoic sedimentary record (Fig. 5). These correlations have been made assuming a mean velocity of $2250 \pm 250 \mathrm{~m} \mathrm{~s}^{-1}$ for the Miocene-recent interval and $2910 \pm 10 \mathrm{~m} \mathrm{~s}^{-1}$ for the Oligocene one (velocity from Garlizenn-1 exploration well; Maillard, 1982).

\section{Results}

\subsection{Seismic stratigraphy}

Sparker seismic profiles image the sedimentary succession from Paleogene to Present from the median shelf to the shelf break. Six seismic units and one sub-unit have been identified (U1 to U6 and U6b) separated by six bounding surfaces (S1 to S6). Seismic characteristics of units and surfaces are described in Table 1. Each unit is composed of one seismic facies that does not vary significantly laterally. In the following section, we describe the seismic stratigraphy in terms of geometry and stacking pattern. We also propose both lithology and stratigraphic position for units when they are documented by subsurface samples, by correlations to surfaces at PENMA-1 well (Preux, 1978), and on the basis of former studies (e.g. Vanney et al., 1972; Guillocheau et al., 2003).

\subsubsection{Seismic unit 1 (U1)}

$\mathrm{U} 1$ is the lower most unit identified on seismic data. As a result, no basal boundary is visible on seismic data. Its seismic facies shows chaotic and locally steep reflections (Table 1 ). It crops out along the present day coastline where it has been sampled (Fig. 5). It consists of metamorphic (micaschists) and crystalline (granites) Paleozoic rocks deformed during the Variscan orogeny (Audrun and Lefort, 1977). It therefore forms the basement of the AS. The upper boundary of U1 is a clear erosion surface (S1) and represents the base of the sedimentary succession of the AS.

\subsubsection{Seismic unit 2 (U2)}

U2 lies directly on the Variscan basement where it presents few onlap terminations on S1. Its thickness is unclear but probably exceeds $400 \mathrm{~ms}$ (Fig. 5). U2 is made up of parallel and continuous reflections (Table 1 ) characteristic of well-bedded marine sediments. U2 is sampled in PENMA-1 and at several locations over the inner shelf where it corresponds to Paleogene chalks, calcareous mudstones and sandstones with rare terrigeneous-rich beds (Andreieff et al., 1968; Barbaroux et al., 1971; Bouysse et al., 1974; Delanoë and Pinot, 1974; Delanoë et al., 1975; Preux, 1978). U2 is bounded above by erosion surface S2 highlighted by toplap terminations (Figs. 4 and 5) that reflects a slight regional tilt $\left(<0.5^{\circ}\right)$. U2 is affected by brittle deformation with NW trending sub-vertical faults and gentle folds (Figs. 1, 4 and 5).

The presence of the thick Cretaceous section (c. $500 \mathrm{~m}$ ) identified in the lower third of PENMA-1 (Fig. 3) is not attested at the seafloor, over the inner shelf, between basement and U2. This may be due to a landward thinning and/or onlap of the series as visible in petroleum conventional seismic data (unpublished petroleum data).

\subsubsection{Seismic unit 3 (U3)}

U3 is a $40-50$ ms-thick unit characterized by discontinuous and slightly wavy very high-amplitude reflections (Table 1 ). It is bounded below by unconformity S2 and above by S3 that shows rather little erosion except on line 20-670 (Fig. 5). No seafloor samples have been collected in the area where the unit may crop out. Nevertheless, U3 correlates geometrically to the upper part of the Oligocene series (Chattian?) at PENMA-1 (Fig. 5) where it is made up of shallow marine coral-rich bioclastic sandstones (Fig. 3). Discontinuity and wavy forms of reflections within U3 may correspond to small coral reefs or mounds. The mapping extent of U3 is unclear but should consist in a narrow corridor seaward from U2. Tectonic deformation style affecting
U3 is similar to U2 but in an evident lesser proportion (Figs. 4 and 5). This observation and the tilting of $\mathrm{U} 2$ suggest that a deformation phase occurred during Paleogene with a probable culmination between Late Eocene and Late Oligocene. Such a phase is described by several regional studies and syntheses and corresponds to the Pyrenean compressive tectonic phase s.l. (Gély and Sztràkos, 2001). It is supposedly responsible for 1) the inversion in the English Channel documented between the Mid-Late Eocene and Early-Oligocene (Ziegler, 1987; Evans, 1990), 2) the sedimentary hiatus in the Bay of Biscay (Hailwood et al., 1979), and coincides with the contemporaneous uplift of North Atlantic margins (Anell et al., 2009 and references herein). This phase may have partly triggered the development of S2 unconformity.

\subsubsection{Seismic unit 4 (U4)}

$\mathrm{U} 4$ is a 100 to 150 ms-thick unit made up of subparallel, continuous and low amplitude reflections (Table 1 ). It shows downlap terminations on its lower boundary S3 and an overall progradation pattern interrupted by transgressive phases of a lesser order evidenced by onlap surfaces (Figs. 4 and 5). The seismic facies suggest well-bedded fine grained deposits (mudstones and siltstones). U4 is topped by a widespread erosion unconformity that is characterized by toplap terminations of the underlying reflections (Figs. 4 and 5). This erosion surface is more or less penetrative into the underlying sediments and locally shows clear deep incisions on several profiles (Figs. 4-6). Very few seafloor samples have been collected in the area (Fig. 1) and mainly consist in Miocene calcareous marls and Aquitanian bioclastic limestones (Andreieff et al., 1968). At PENMA-1, S3 and the lower part of $\mathrm{U} 4$ respectively correlate with a thin poorly-sorted terrigeneous sandstone bed and a Miocene mixed marine terrigeneous-calcareous mudstone. This unit may find lateral equivalents in the Miocene "faluns" (shallow marine mixed bioclastic and terrigeneous coarse sands) that are well-documented onshore (Brittany, Anjou, and Tourraine areas; Lécuyer et al., 1996; Néraudeau, 2003).

These observations suggest that S3 developed at the transition between a documented Oligocene sea-level low and a Miocene sealevel high (Haq et al., 1987) evidenced by the change from shallow marine limestones with corals to transgressive glauconitic sandstone then prograding marine mudstones (Preux, 1978). The upper part of U4 is not sampled or described in PENMA-1 (no recovery), it is thus lacking reliable lithology and age calibrations (see discussion). The upper limit S4 presents evident erosion features including irregular toplap/truncation surface with channel-like incisions (Figs. 4-6). As for S2, the toplap terminations evidenced a slight seaward tilt $\left(<0.5^{\circ}\right)$ of the sedimentary section (Fig. 5). The age calibration of S4 cannot be directly determined from existing samples and different hypotheses are addressed in the discussion section.

\subsection{Buried channel incisions of S4}

Among several unconformities identified in the seismic stratigraphy of the AS, S4 is the oldest to exhibit a deeply incised surface. Careful study of available seismic profiles allows a better understanding of the processes resulting in the generation of S4 and associated erosion features (Figs. 4 and 6). Incisions present (1) major and deeper channels with (2) several associated secondary channels (tributaries), separated by (3) strath terraces developing in (4) a wider valley. These observations are in agreement with a fluvial and thus subaerial origin for the incisions (Posamentier, 2001). A possible karstic origin for these features is neglected here because the incised lithologies contain a terrigeneous fraction (PENMA-1, Preux, 1978). The incision depth of the major channel and the valley shape along transversal profiles vary dramatically (Fig. 6). On profiles 7 and 26 (Fig. 6A and C), the vertical incision, from the valley edges to the channel bottom, reaches $30 \mathrm{~ms}$ and $60 \mathrm{~ms}$ respectively $(30 \mathrm{~m}$ and $60 \mathrm{~m}$ at $2000 \mathrm{~m} \mathrm{~s}^{-1}$ ) and is strongly localized, whereas, in between, 
Table 1

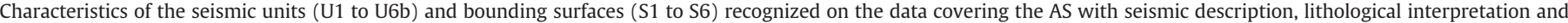
examples from GeoEtel-2008 survey.

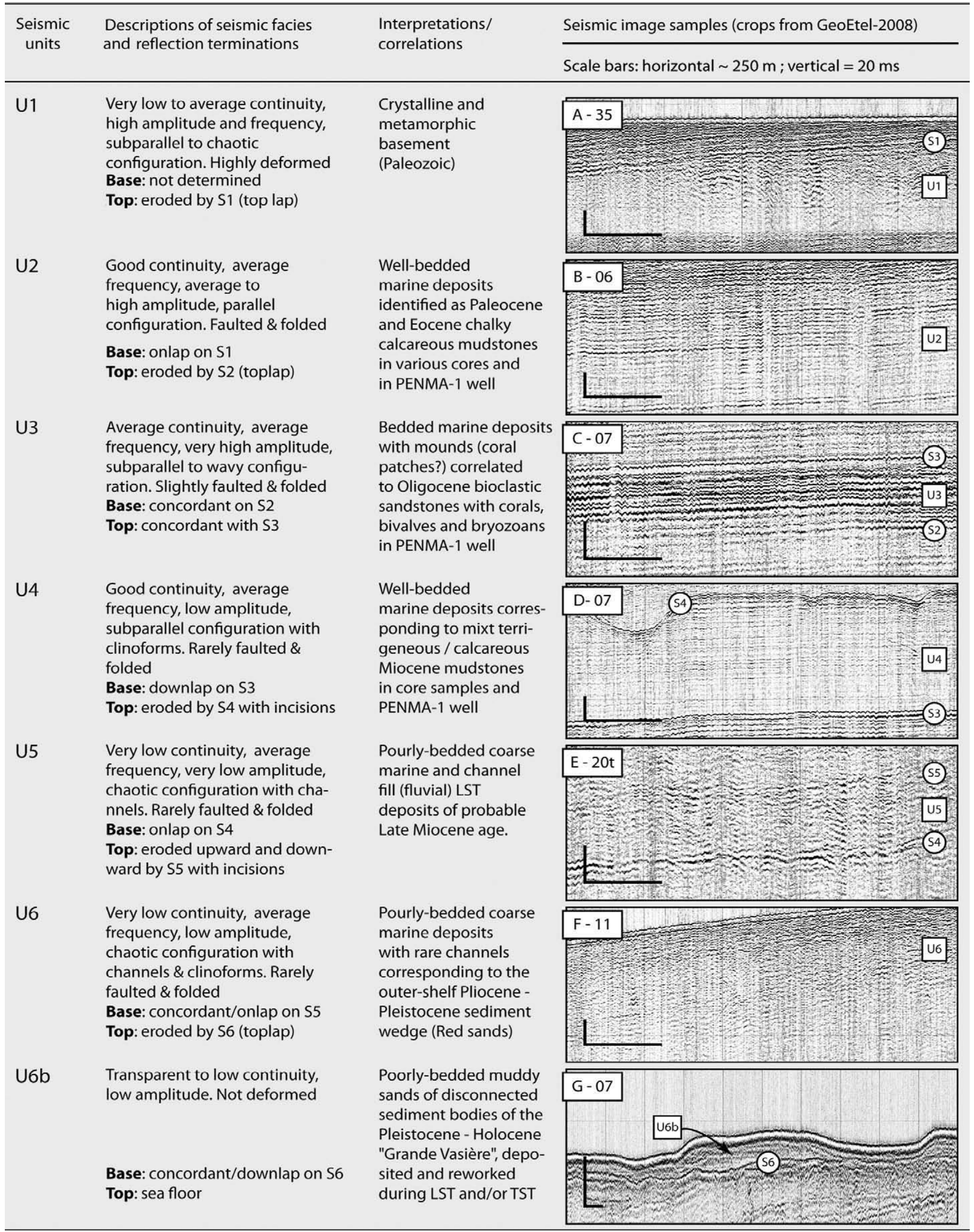




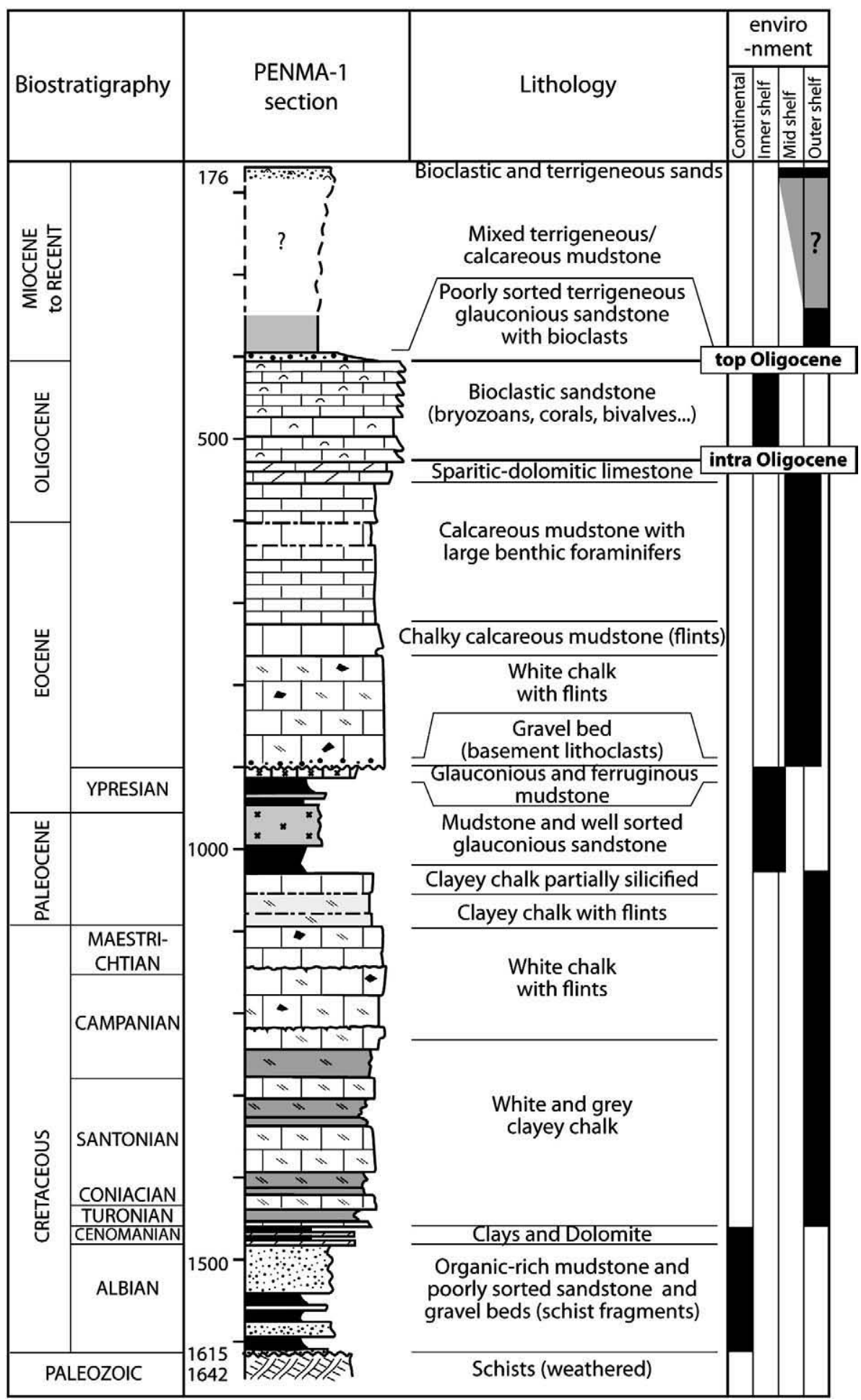

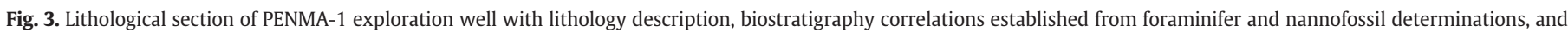

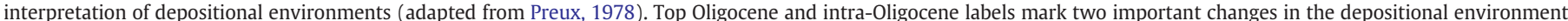
settings that may correlate to seismic unconformities.

on profile 22, incision is less deep ( $10 \mathrm{~ms} ; 10 \mathrm{~m}$ at $2000 \mathrm{~m} \mathrm{~s}^{-1}$ ) (Fig. 6B). Likewise, the shape of channels on seismic profile shows a clear variability from V-shape (e.g. Profile 26, Fig. 6A) to U-shape (e.g. Profile 7, Fig. 6C) with more or less symmetry. This is in agreement with seismic profiles crossing sinuous valley reaches with variable azimuth angles (Fulthorpe et al., 1999). The density of seismic profiles allows the mapping of a paleo-fluvial network in that area (Figs. 7 and 8). We tentatively trace four distinct valleys, labeled A, B, C and D, from west to east, by correlating incisions between profiles (Fig. 8). Valleys strike to the NE-SW, orthogonally to the margin. As incision depth fades seaward and as S4 and associated valleys are eroded landward by S6, the network cannot be traced over more than 30$40 \mathrm{~km}$ (Fig. 8). Our interpretations suggest a connection of both valleys B and C downstream. The valley fill deposits (base of U5) are made up of several sub-units separated by U-shaped erosion surfaces that laterally incise and widen the preexisting main channel (e.g. 

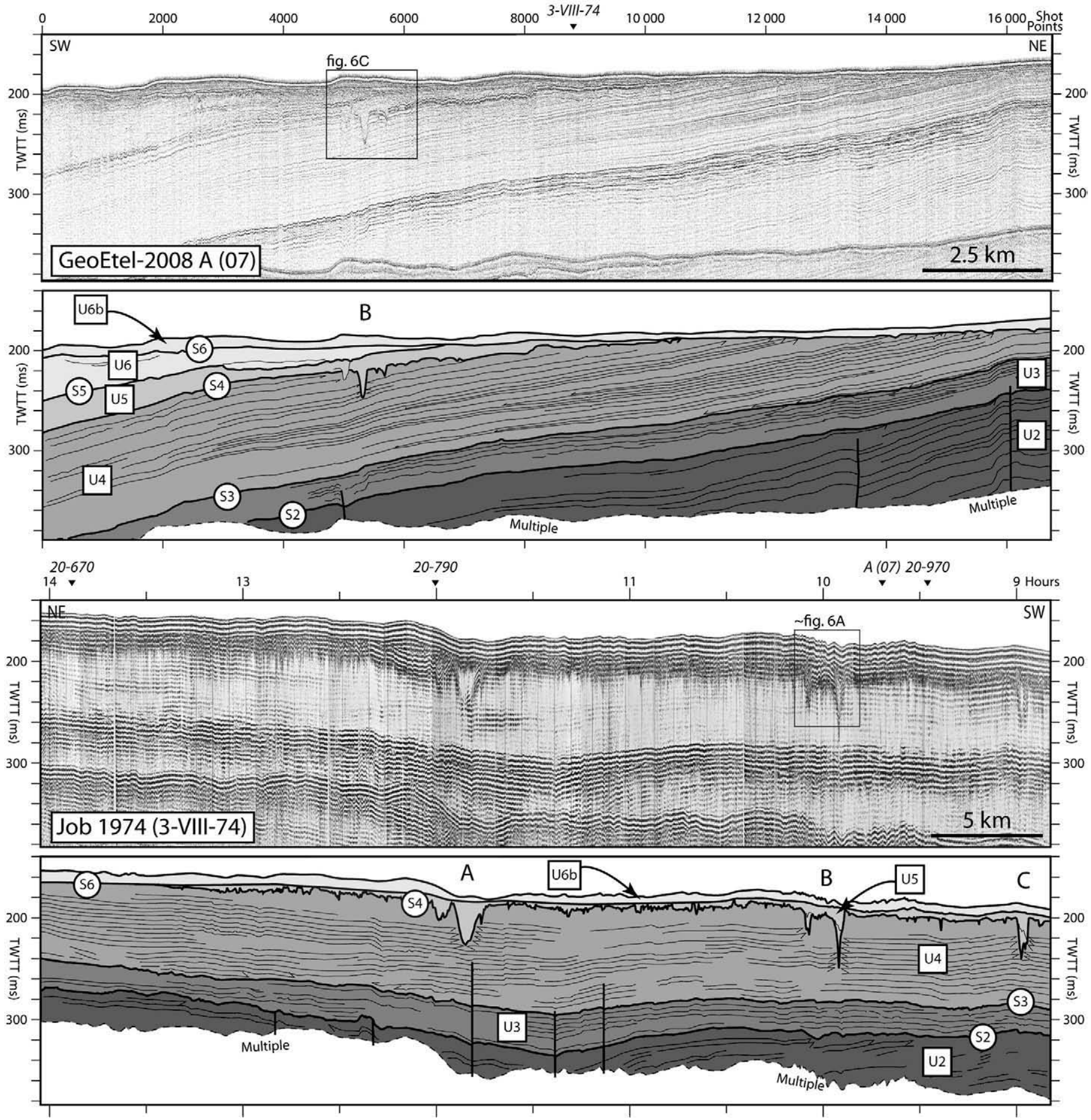

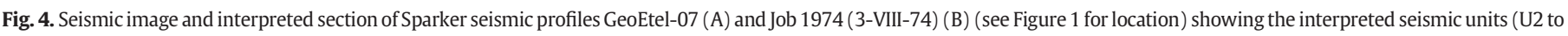

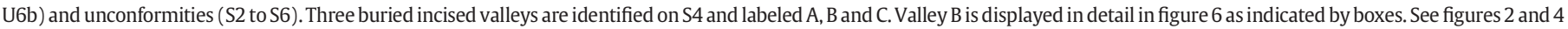
for Location of profiles. Note that the zoom on Fig. 6a. is a crop of GeoEtel 2008 - 26 but is indicated by a box on Job 1974 (3-VIII-74) as both profiles are similar in location.

profile 26, Fig. 6A). On profile 7, younger channelized incisions are visible and one of them truncates the main erosion surface S4 (Fig. 6C). Therefore, generation and reshaping of S4 erosion surface ends after deposition of U5 starts.

\subsubsection{Seismic unit 5 (U5)}

U5 is a 40-50 ms-thick lens-shaped unit that thins both landward and seaward (Fig. 5). It shows very chaotic and discontinuous reflections with channels and onlap terminations on S4 (Table 1). Such seismic facies suggests sandy sediments. Deposits in the basal part of U5 fill the S4 incisions and present U-shaped erosion surfaces that locally incise U4. Above, the upper-boundary S5 shows unusual characteristics with possible channel incisions (Figs. 4 and 5) and a seaward truncation of several U5 reflections (Fig. 5). The age of U5 is not defined as but intersection between S5 and sea floor corresponds to the base of the Pliocene-Pleistocene sedimentary succession.

\subsubsection{Seismic Unit 6 (U6)}

U6 is a $>200$ ms-thick unit that corresponds to the seaward most seismic unit individualized in this study. It lies conformably over S5 


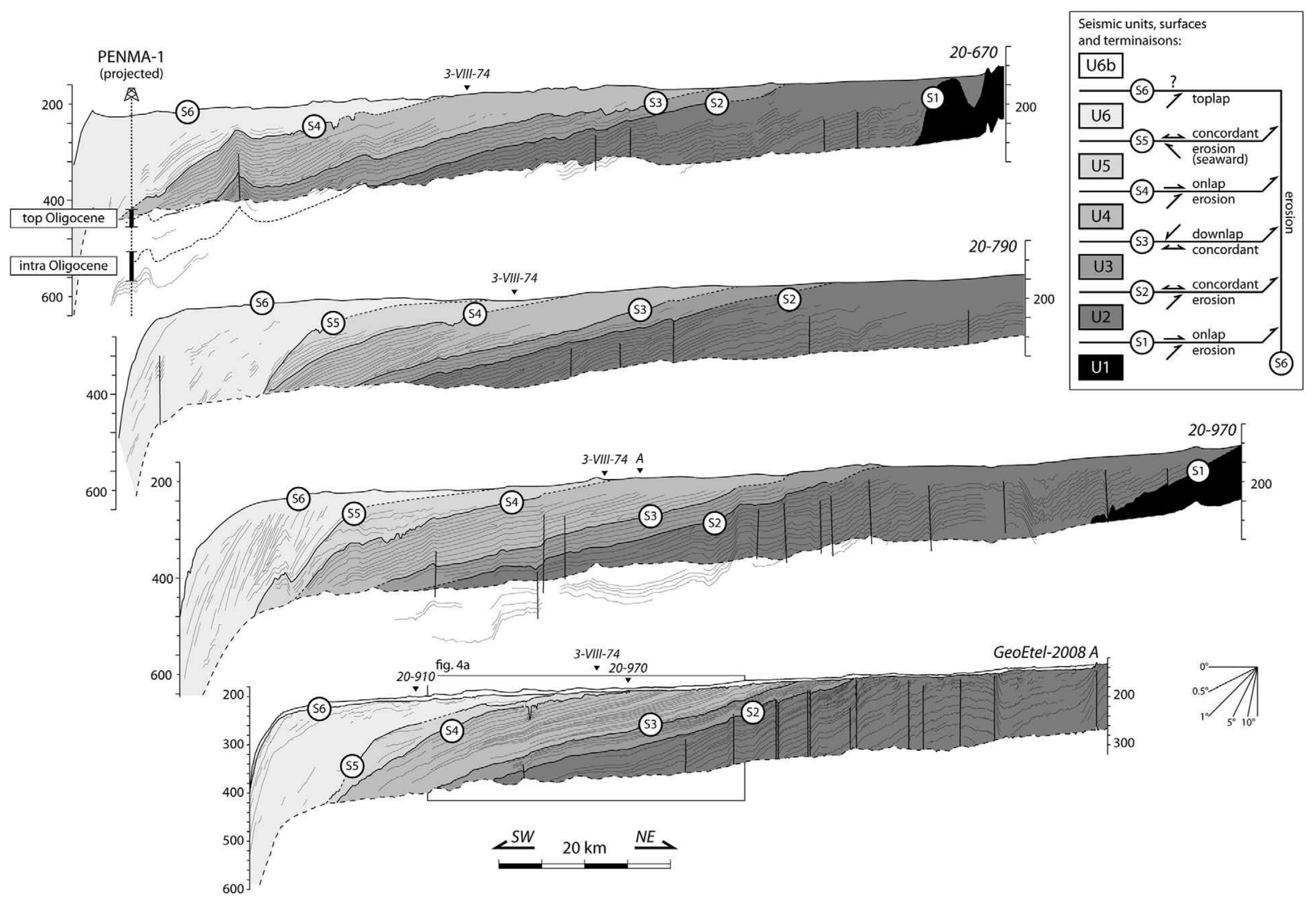

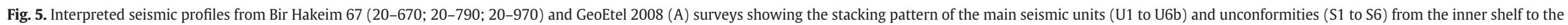

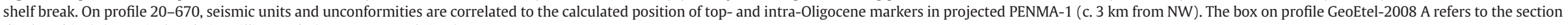
displayed in (A). Vertical scale in milliseconds (two way travel time). 

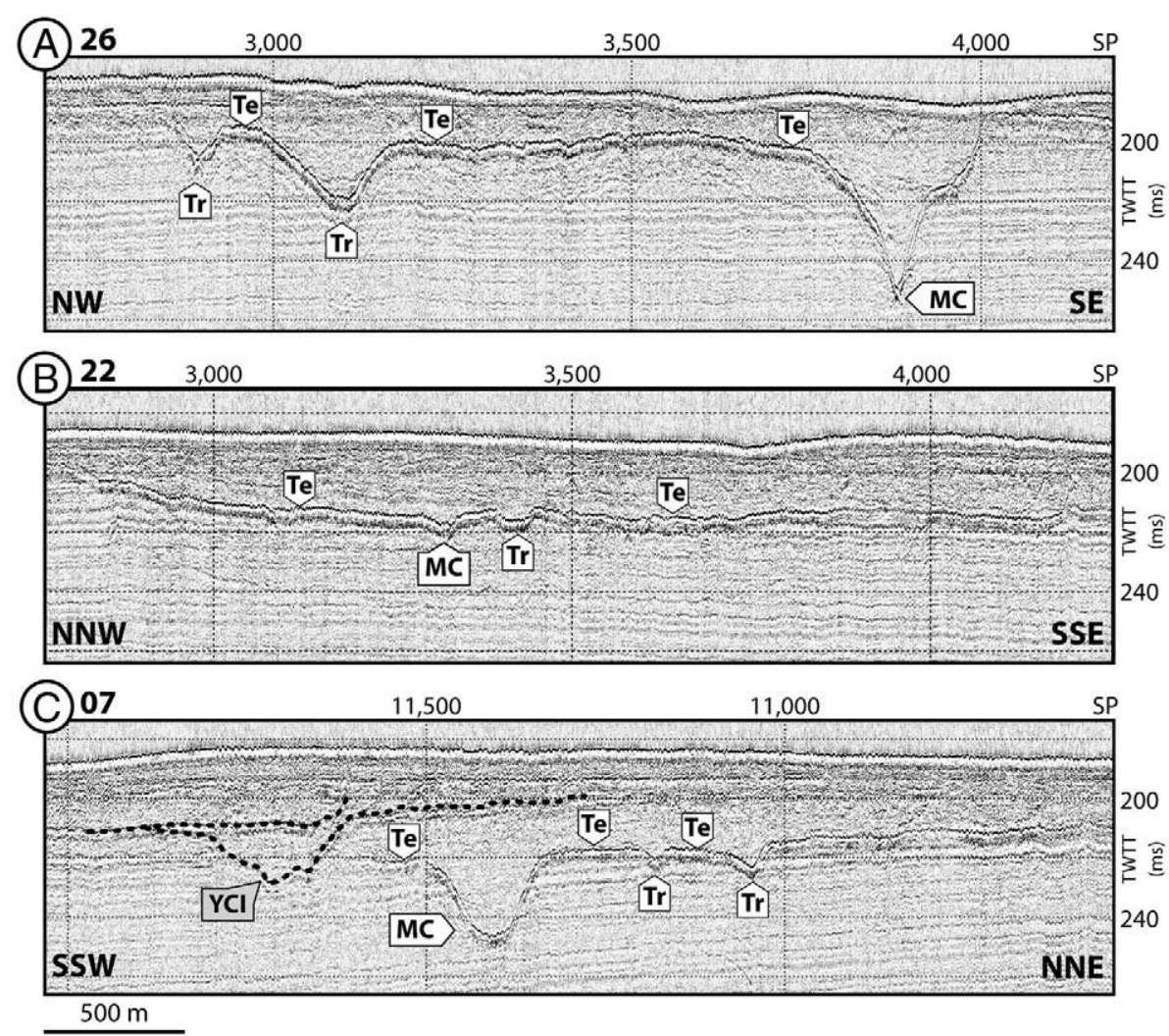

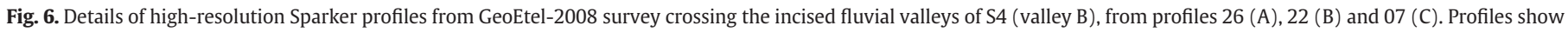

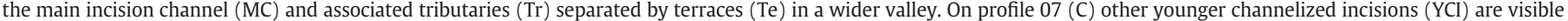
that cut the major erosion surface S4. Vertical axis in ms (TWTT: two-way travel time) and horizontal axis show Shot Point number (SP). See Figs. 1 and 3 for location.

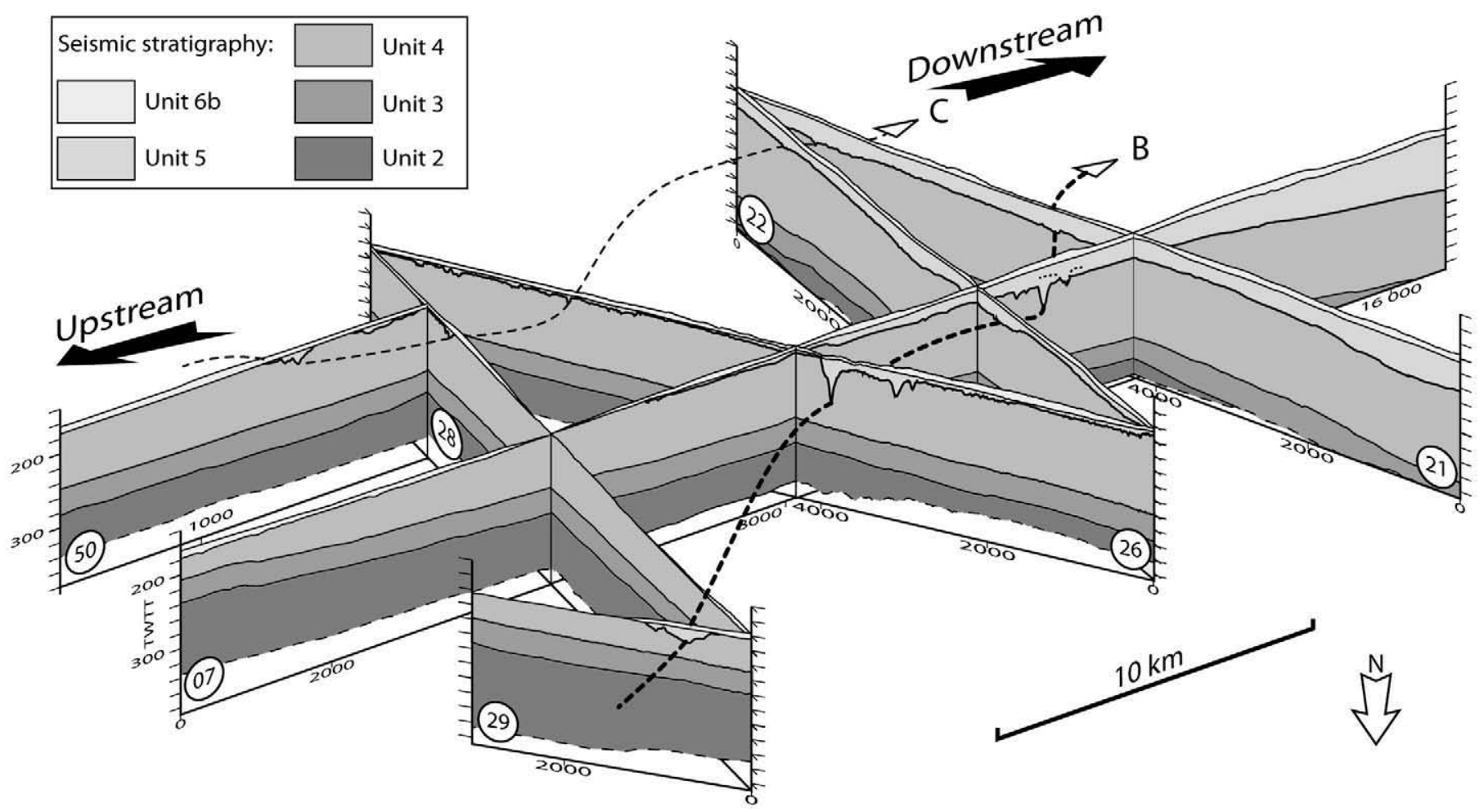

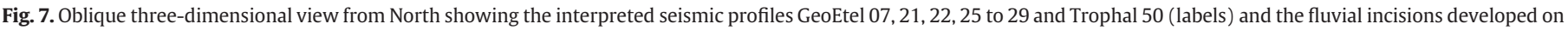

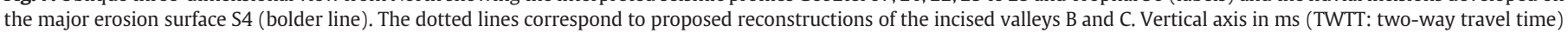
and horizontal axis show Shot Point number (SP). 


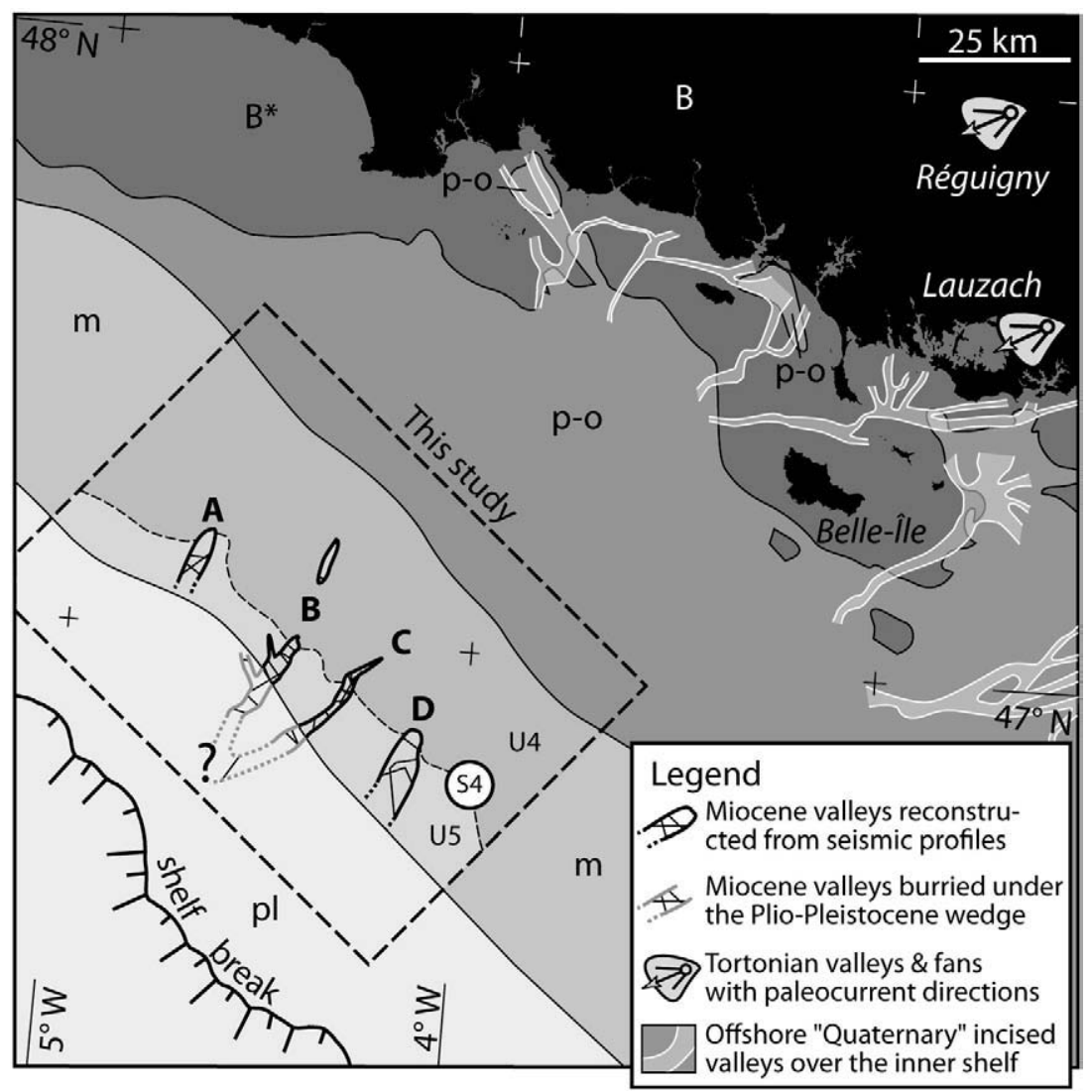

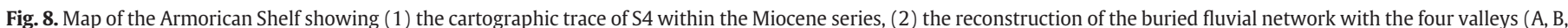

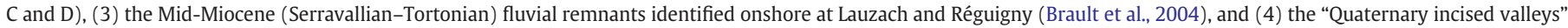

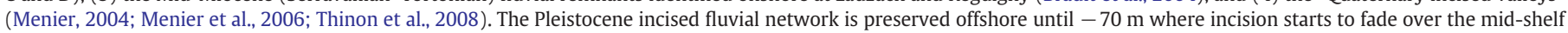
(Menier et al., 2006). Direct connection between networks is precluded by erosion onshore and by the major erosion surface S6 of the AS offshore.

and reflections are discontinuous, chaotic with possible channels (Table 1 ) and show a seaward dip of c. $5^{\circ}$ (Fig. 5). The seismic facies is similar to U5 suggesting sandy material. The upper boundary of U6 corresponds to the "flat" sea floor that forms the morphology of the shelf. U6, as well as all the other seismic units (U1 to U5) is strongly eroded at the sea floor. On GeoEtel-2008 seismic data (e.g. Figs. 4-6), this erosion surface is resolved as 1 ) a proper erosion surface topped by 2) a thin and discontinuous sediment cover (sub-unit U6b). This sediment cover is made up of unconsolidated mixed terrigeneous and bioclastic clayey sands of Holocene age. The age calibration of U6 cannot be attested with certainty as no sea floor sample exists in the area except for U6b. Nevertheless, U6 being the last and thus youngest unit of the AS we propose a Pliocene-Pleistocene age. This is also supported by the complex internal stacking pattern with several unconformities that may illustrate the impact of the Plio-Pleistocene eustasy variations. S6 may therefore correspond to the last member of a series of coincident erosion surfaces resulting from the dramatic high-amplitude Pleistocene sea-level variations.

\subsection{Summary}

Our seismic interpretation allows the identification of six seismic units separated by major unconformities. The first unit U1 corresponds to the Paleozoic basement and the following ones represents the Cenozoic sedimentary cover of the Armorican Shelf. Lithology, calibrated from core samples and PENMA-1 well progressively evolves from a biogenic carbonate-dominated sedimentation to mixed bioclastic-terrigeneous deposits throughout the whole sedi- ment section. Several unconformities show erosion features and both S2 and S4 record phases of Cenozoic seaward tilting of the margin. S4 is the oldest erosion surface to exhibit deeply incised fluvial valleys. It seems to mark an important step in the transition between the two sedimentation styles stated above. In the following section we discuss the age calibration of S4, the deciphering of the various controlling parameters that lead to its generation, the morphology of the valley reaches, and its significance in terms of paleogeography and evolution of the shelf morphology.

\section{Discussion}

Existence of fluvial channels on the AS continental margin indicates that rivers were once flowing over the emerged shelf but the stratigraphic position of the incised erosion surface $\mathrm{S} 4$ within sedimentary succession is still unclear. These channel-like incisions had already been described by Pinot (1974) and associated to a continuous Late PliocenePleistocene fluvial network extending over the AS and connecting onshore valleys to the slope canyons. Nevertheless, careful study at the newly acquired seismic data reveals that 1 ) the channels are associated with the tilted Neogene S4 erosion surface and that 2) no direct connections to the inner-shelf paleovalleys and/or slope canyons can be traced.

\subsection{Age calibration of $\mathrm{S} 4$}

Seismic units (U4 and U5) on both sides of S4 have not been properly dated making age calibration of this surface rather 


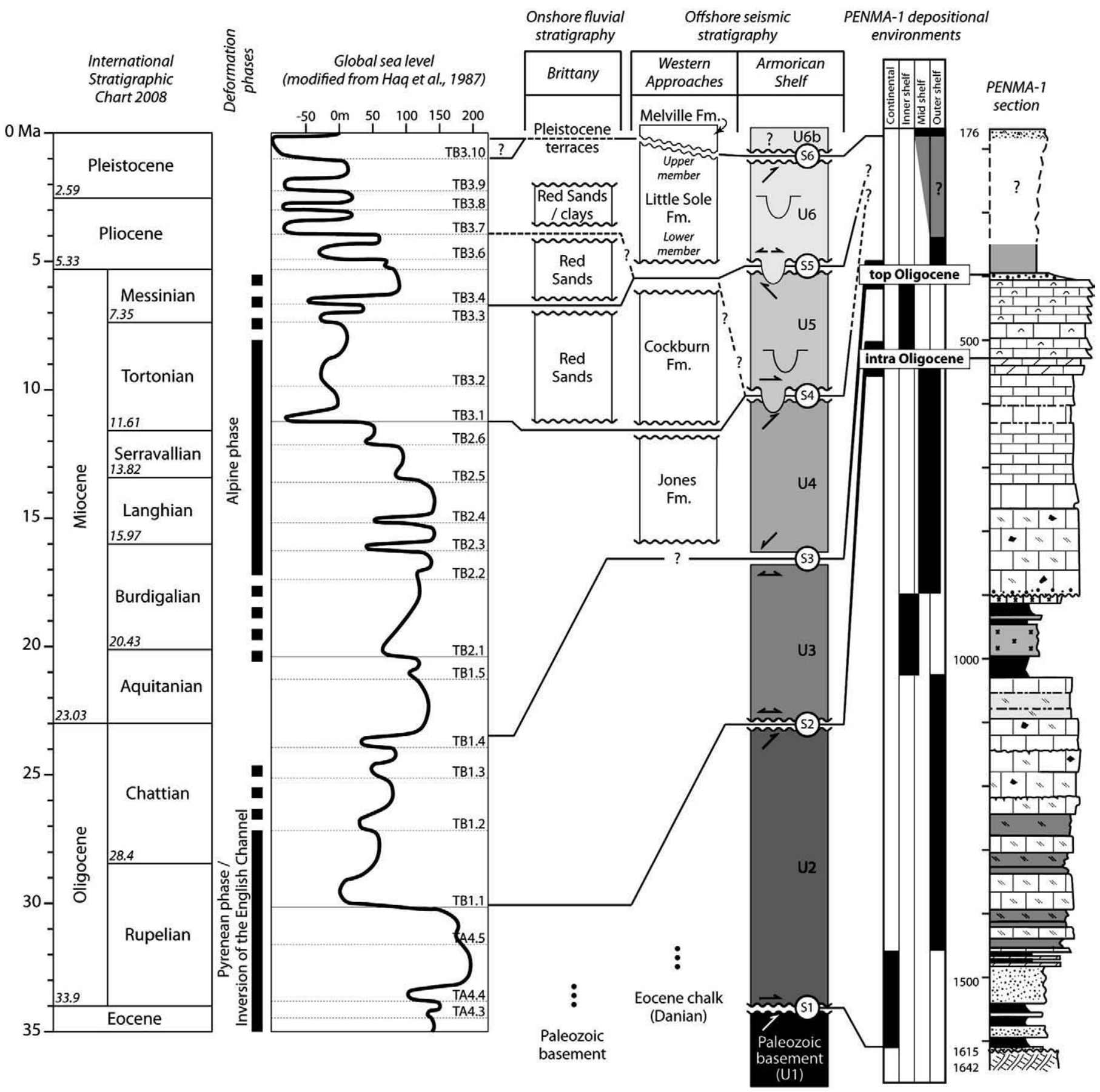

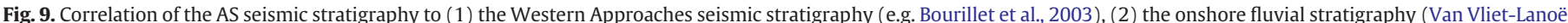

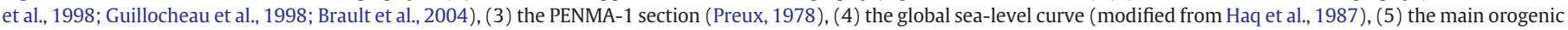
phases affecting the western Europe, and (6) the International Stratigraphic Chart of 2008 from the International Commission on Stratigraphy (www.stratigraphy.org).

speculative. Our interpretation and correlations to PENMA-1 indicate that $\mathrm{U} 3$ and the base of $\mathrm{U} 4$ are of Late Oligocene and Early Miocene age respectively, and that a Pliocene-Pleistocene age is confidently attributed to U6. Therefore, the age of S4 is comprised between Early Miocene and at some stage in Pliocene. By analogy to the documented stratigraphy of the nearby Western Approaches (Fig. 9) where incised valleys are also identified (Evans and Hughes, 1984; Powell, 1988; Reynaud et al., 1999; Bourillet et al., 2003; Stewart and Davies, 2007), two hypotheses can be formulated as follows. These hypotheses are then tested using the event timing of regional and global controlling parameters (tectonic deformation, eustasy, and climate) that have been recorded in Western Europe and in other remote margins.

\subsubsection{Hypothesis 1 - "Late Miocene-Pliocene" age model}

In this model, 1) $\mathrm{U} 4$ is the lateral equivalent of both Jones and Cockburn formations that are of Early to Mid-Miocene (AquitanianSerravallian) and of Mid- to Late Miocene age respectively (Evans and Hughes, 1984; Powell, 1988), and 2) U5 and U6-U6b correspond to both the Plio-Pleistocene Little Sole formation and the PleistoceneHolocene Melville formation respectively. In such context, S4 and associated valleys are likely of Late Miocene-Pliocene age. This is in agreement with both the Messinian age preferred by Bourillet et al. (2003) and the Late Pliocene age proposed by Reynaud et al. (1999) for the lateral equivalent of S4 in the Western Approaches. 


\subsubsection{Hypothesis 2 - "Mid-Late Miocene" age model}

In this model, $\mathrm{U} 4$ has only the Jones formation as lateral equivalent whereas the Cockburn formation correlates with U5, and both U6 and U6b are equivalent to the Little Sole and the Melville formations. Thus S4 developed earlier, close to the Mid-Late Miocene boundary. Such an attribution is also consistent with the study of Bourillet et al. (2003) that indeed proposed an age ranging from c. $12 \mathrm{Ma}$ (SerravallianTortonian) to c. $5 \mathrm{Ma}$ (Messinian). Late Pliocene incised valleys (Reynaud et al., 1999) would find more suitable equivalents within U6 where channels are described.

Without reliable ages, discussing S4 age models requires to determine the possible control parameters that lead to S4 development and the related timing of events. Fluvial incisions into marine deposits evidence the emergence of the shelf that implies an important relative sea-level (base-level) fall. Such a fall find its origin in either (1) a tectonic deformation (local uplift) and/or (2) an eustatic fall (global).

\subsection{Cenozoic tectonics}

Tectonic deformation within the sedimentary succession of the AS and identified on seismic data is characterized by sub-vertical faults and associated folds that affect mostly the seismic unit U2 (Paleocene-Eocene). Angular unconformity S2 seals most of the brittle deformation and only few faults traverse the following seismic units (Figs. 4 and 5). S4 corresponds to another angular unconformity that shares several features with $\mathrm{S} 2$, including toplap terminations of $\mathrm{U} 4$ reflections.

Over the Bay of Biscay area and over the AS, the Cenozoic tectonic deformation is attributed to the alpine orogeny s.l. (Fig. 9). Two major phases are recognized in the literature (Ziegler, 1990; Bourrouilh et al., 1995). The Pyrenean phase s.l. extends from Eocene to MidOligocene (Gély and Sztràkos, 2000, 2001). It is expressed on the AS as the series of sub-vertical faults (reactivated Variscan structures) and folds visible in the contemporaneous seismic unit U2 (Bouysse and Horn, 1971; Delanoë, 1988), and as the Oligocene angular unconformity S2 that mostly seals this deformation (Figs. 4 and 5). Contemporaneously with the Late Pyrenean phase is the first basin inversion of the Western Approaches Trough (Ziegler, 1987). The second phase of deformation is related to the Miocene Alpine contractional phase. Its record on the AS may correspond to the play of part of the Paleogene sub-vertical faults that affect seismic units from U3 to U6 (Oligocene to recent). Similarly to S2, erosion surface $\mathrm{S} 4$ is an angular unconformity that also highlights and seals a Neogene tilt of the AS toward the SW (Figs. 4 and 5). This phase is also contemporaneous with a new phase of inversion in the Western Approaches Trough, and both are of Mid-Late Miocene to Pliocene age (Ziegler, 1987, 1990; Guillocheau et al., 2000). Thus, Neogene tectonic deformation phases provide a good framework to explain the various features identified on seismic data. Unfortunately, the duration of these phases and the poor age control on their pulses preclude any accurate age calibration of S4. Alternatively, northwest European passive margins undergone both tilting and sagging attributed to mantle-driven processes during Cenozoic (Praeg et al., 2005) but the timing and signature of deformation differ from what is recorded along the AS. Finally, looking at the present day architecture of the AS margin (Fig. 4), the angular erosion unconformity S6 attests a PlioPleistocene tilt of the margin that has increased the subsidence of the outer shelf and the burial and preservation of S4 incised valleys.

\subsection{Cenozoic eustasy}

During Cenozoic, sea level has undergone important and abrupt changes (Fig. 9) accompanying the overall transition from the Mesozoic Early-Cenozoic greenhouse to the Quaternary icehouse conditions (Haq et al., 1987, 1988; Miller et al., 1998, 2005). One example is the postulated Mid-Oligocene eustatic lowstand visible on the eustatic curve of Haq et al. $(1987,1988)$ close to the RupelianChattian boundary, or alternatively attributed to an earlier Oligocene cooling event by Miller et al. (2008). According to different studies the estimated amplitude of the fall varies from - $160 \mathrm{~m}$ (Haq et al., 1987) to $-55 \mathrm{~m}$ (Miller et al., 2005). On the AS, this documented Early- or Mid-Oligocene eustatic fall correlates fairly well with the S2 erosion unconformity and is also illustrated by the transition from the outershelf Eocene marine deposits from shallower inner-shelf Oligocene deposits described at PENMA-1 (Preux, 1978; Guillocheau et al., 2003) (Fig. 3). Thus, the generation of S2 unconformity and its characteristics would result from the combined effects of both tectonic deformation and a eustatic sea-level fall.

Considering the similarity between S2 and S4 unconformities (Fig. 5), and especially the existence of incised fluvial valleys (Figs. 4-6), the generation of S4 would have required a relative sea-level fall following the Oligocene fall event with amplitude similar or greater. One other major climatically-induced sea-level fall documented worldwide for this period starts during the Late Langhian-Early Serravallian (c. $14 \mathrm{Ma}$ ) and culminates around the Serravallian-Tortonian boundary (Mid-Late Miocene boundary at $11.608 \mathrm{Ma}$ - GSSP; Hilgen et al., 2005) (Haq et al., 1987, 1988; Kominz et al., 1998; Miller et al., 1998; John et al., 2004; Miller et al., 2005). The Serravallian-Tortonian boundary correlates to the glacio-eustatic lowstand T3.1 (Haq et al., 1987, 1988) associated with the permanent establishment of the East Antarctic Ice Sheet (Zachos et al., 2001). The amplitude of the Middle Miocene sealevel fall estimated in former studies is still debated with values ranging from $-25 \mathrm{~m}$ to $-180 \mathrm{~m}$ (Haq et al., 1987; Pigram et al., 1992; Miller et al., 1998; John et al., 2004). We propose that S4 and associated channel incisions were completed close to the Serravallian-Tortonian boundary at c. 11.6 Ma with a probable initiation occurring earlier during Late Langhian-Early Serravallian. The onset of the Icehouse and long-term sea-level lowstand conditions would also explain the presence of several younger (e.g. Tortonian and Messinian) channelized erosion surfaces identified within U5 and U6 (Figs. 4 and 5). In addition, Mio-Pliocene fluvial network remnants have been described onshore in Brittany (Guillocheau et al., 1998; Van Vliet-Lanoë et al., 1998) in several places including Lauzach and Réguigny (Fig. 8). The basal fluvial deposits filling the oldest incised valleys have been dated by ESR at $8.7 \pm 1.5 \mathrm{Ma}$ within the Tortonian (Van Vliet-Lanoë et al., 1998; Brault et al., 2004). This suggests a possible Serravallian or Early-Tortonian age for the incision phase. The reconstruction of the Tortonian network provided by Brault et al. (2004) and based on paleocurrent directions shows a southwestward direction for both the onshore Tortonian and the supposedly contemporaneous offshore S4 fluvial networks (Fig. 7). In addition, onshore outcrops exhibit several erosion surfaces and associated fluvial networks (Brault et al., 2004). This configuration is shared by the offshore buried valleys that show several younger incisions (Fig. 6). Thus, both offshore and onshore networks could be genetically linked. Unfortunately, due to the joint effects of (1) the Neogene seaward regional tilting of the AS and (2) the wave abrasion that occurred during the Plio-Pleistocene sea-level fluctuations and gave its shape to the present day AS (polygenetic wave-planed surface), the channelized erosion surface is only preserved $100 \mathrm{~km}$ offshore the present day coastline. Such configuration avoids direct correlations between this distal buried fluvial network and the onshore one. In the same way, the question could be asked about the age of the so-called Quaternary innershelf incised valleys. If a Plio-Pleistocene age for the sedimentary fill sounds reasonable (Menier et al., 2006; Proust et al., 2010), the incision phase could be underestimated (Menier, 2004) and be reassessed to the Mid-Miocene time.

Compared to surrounding areas, a Serravallian-Tortonian boundary age attribution for S4 seems reasonable. Over the North Aquitaine Shelf, Bellec et al. (2009) describe several unconformities showing incised valleys. They propose that these surfaces formed during the successive Langhian to Early-Tortonian sea-level falls, the last one being the most erosive and correlating T3.1 sea-level fall of Haq et al. (1987) as 
proposed for S4 on the AS. The absence of earlier incisions below S4, within U4, may be explained by (1) lower subsidence and sedimentation rates of the AS area that resulted in the stacking of all surfaces in only one (S4) or (2) because incisions occurred landward and have been eroded later (Fig. 5). Over the Western Approaches, the age of the incised valleys is still debated but Bourillet et al. (2003) propose an age ranging from 12 to $5 \mathrm{Ma}$ (Serravallian to Messinian) based on a range of subsidence rates. Such an age range is compatible with our age estimation for S4. Likewise, major erosion unconformities attributed to Mid- to Late Miocene sea-level falls are described in other remote passive margins such as the New Jersey shelf (Fulthorpe et al., 1999), the northern Java shelf (Posamentier, 2001), and the Gulf of Lions (Besson et al., 2005). The sea-level fall at the Serravallian-Tortonian boundary is specifically preferred as the triggering event for several of these surfaces such as in the Gulf of Papua (Tcherepanov et al., 2008) or in the Gulf of Lions (Lofi and Berné, 2008).

We thus favor the second hypothesis, and consequently attribute a Tortonian age to U5 (equivalent of the WA Cockburn formation and the first onshore "Red Sands" (Fig. 9). Erosion surface S5 could be of Messinian or basal Pliocene age (Haq events TB3.4 or 3.6). U6 would therefore correspond to the Pliocene-Pleistocene outer-shelf sedimentary prism and is a lateral equivalent of the Little Sole formation.

The Serravallian eustatic fall would have thus progressively exposed the shelf of the AS, thus creating the major unconformity S4 and associated channels. This event took place while the whole AS undergone a regional tilt related to the Alpine orogenic phase. It results that S4 developed also as an angular unconformity. This tilt has induced a local uplift of the area thus increasing the effect of eustasy on the relative sea-level fall, and enhancing the stratigraphic signature S4.

\subsection{Significance of the valley morphology}

At its lowest, the Serravallian-Tortonian sea level may have reached depth close to or even below the smooth and rounded clinoform breakpoint. Potential connection between S4 incised valleys and hypothetical Mid-Miocene slope canyons, is not yet demonstrated. This is mainly due to the scarcity of data and their rather low penetration where the Mid-Late Miocene strata are buried below the thick Plio-Pleistocene wedge. Nevertheless, when looking at the vertical incision depth of the four valleys, it tends to decrease southwestward (seaward) indicating that valleys and canyons are not directly connected.

Alternatively, depth of vertical fluvial incision on shelves is often considered as a proxy for estimating the depth reached during the sealevel lowstand. Concerning the valleys described in this study, the use of the depth of channels, to estimate the contemporaneous sea-level appears problematic. The observed variability of depth incision of one valley between seismic sections corresponds to large-scale undulations of the river bottom longitudinal profile and suggests a riffle-pool sequence morphology developing on a sinuous channel (Richards, 1982; Lofthouse and Robert, 2008). Testing this hypothesis would require additional data in order to constrain the three-dimensional morphology of the channels, the length of the riffle-pool sequence, and finally, to discuss the potential river characteristics (e.g. water discharge, sediment load, and grain-size). The "pool" areas may also be controlled by the confluence of one or more tributaries with the main channel. In addition, we consider that the young and unconsolidated lower to Middle Miocene series, incised by the Mid-Miocene rivers, has played a significant role by facilitating the incision in the "pools" areas. Such variability of the depth of incision thus precludes accurate and reliable estimation of the depth reached by the sea level during the Late Serravallian-Early-Tortonian lowstand. Moreover, the tectonic tilt of the margin and the associated uplift of the area, evidenced by the angular unconformity S4, have also played a role in the relative amplitude of the sea-level fall. Additional data are needed to better understand the valley morphology and its relation with the shelf edge.

\section{Conlusions}

High-resolution seismic data recently acquired on the Armorican Shelf reveal the presence of buried channel incisions developed on a widespread erosion surface S4, c. $100 \mathrm{~km}$ from the present day coastline. Reconstruction of the paleo-fluvial network reveals the sinuosity of the valleys and the potential riffle-pool morphology. These incisions are the same described by Pinot (1974) but considering their stratigraphic position, a Quaternary age is unlikely. Based on the seismic interpretation of the AS stratigraphy, correlation to the eustatic sea-level curve of Haq et al. (1987), and from comparison to other margins, we propose that the unconformity S4 is rather of MidNeogene age. We also assume that the relative sea-level fall required for creating such fluvial incisions on an exposed shelf was predominantly controlled by eustasy. As an angular unconformity, S4 developed contemporaneously with a tilting of the margin related to the Miocene Alpine orogenic phase. The associated uplift may have increased the relative sea-level fall in the area, thus favoring the emersion of the shelf. The most suitable eustatic fall event in terms of timing and amplitude initiated in the Serravallian and culminated at the Serravallian-Tortonian boundary. Therefore we proposed an age of c. 11.6 Ma for the completion of these incisions. Such an attribution needs to be validated by new samples as other potential ages are proposed in other studies for surrounding analogues. These valleys correlate well in both age and direction with Mid-Miocene incised valleys described onshore, over Brittany. The question remains on the age of the incision phase of the inner-shelf Quaternary incised valleys. This improves our knowledge of the local Miocene paleogeography. Together with recent results on the North Aquitaine shelf, these results provide new arguments that tend to confirm the significance of the eustatic fall at the Serravallian-Tortonian transition and its record on the northern margin of the Bay of Biscay. The expression of the Serravallian-Tortonian boundary on the AS margin marks the beginning of high-amplitude eustatic fluctuations (icehouse) culminating during Pleistocene and creating its present day plateau morphology (polygenetic wave-planed surface). The variation in the depth of incision characteristic of riffle-pool morphology limits the ability to quantify the relative and/or absolute sea-level fall. We finally point out that the detailed knowledge of the valley three-dimensional morphology (riffle-pool, meander) is requested before interpreting the significance of the incision depth in terms of local and global controls. Additional data acquisition and interpretation are requested to better constrain the geometry of the network and the relationship with the shelf edge and potential interactions with Miocene slope canyons.

\section{Acknowledgments}

This study has been funded by société Lafarge and by the Université de Bretagne-Sud, within the framework of the PERIARMOR project, (Chief scientist: Dr. David Menier). The authors would like to thank Craig Fulthorpe and an anonymous reviewer for their pertinent comments on the earlier versions of the manuscript. The seismic acquisition material has been provided by the University of Rennes 1 - Géosciences Rennes (Dr. Jean-Noël Proust). The authors also wish to thank Alexandre Dubois, Florent Scalliet, and Camille Traini for their collaboration, discussions, and assistance during the GeoEtel-2008 survey. We are also indebted to the crewmembers of the CNRS-INSU vessel "Côte de la Manche".

\section{References}

Andreieff, P., Bouysse, P., Horn, R., L'Homer, A., 1968. Données récentes sur l'Eocène au large de la Bretagne méridionale. Compte Rendu. Sommaire des Séances. Société Géologique de France 5, 161-162.

Anell, I., Thybo, H., Artemieva, I.M., 2009. Cenozoic uplift and subsidence in the North Atlantic region: geological evidence revisited. Tectonophysics 474, 78-105. 
Audrun, C., Lefort, J.-P., 1977. Géologie du plateau continental sud armoricain entre les îles de Glénan et de Noirmoutier. Implications géodynamiques. Bulletin de la Société Géologique de France 7, 395-404

Barbaroux, L., Blondeau, A., Margerel, J.-P., 1971. Présence d'Yprésien fossilifère sur le plateau continental à l'Ouest du plateau du Four (Loire-Atlantique). Comptes Rendus de l'Académie des Sciences 273, 12-15.

Bellec, V.K., Cirac, P., Faugères, J.-C., 2009. Formation and evolution of paleo-valleys linked to a subsiding canyon, North Aquitaine shelf (France). Comptes Rendus Geosciences 341, 36-48.

Besson, D., Parize, O., Rubino, J.-L., Aguilar, J.-P., Aubry, M.-P., Beaudoin, B., Berggren, W.A., Clauzon, G., Crumeyrolle, P., Dexcote, Y., Fiet, N., Iaccarino, S., Jiménez-Moreno, G., Laporte-Galaa, C., Michaux, J., Von Salis, K., Suc, J.-P., Reynaud, J.-Y., Wernli, R., 2005. Latest Burdigalian network of fluvial valleys in southeast France (western Alps), characteristics, geographic extent, age, implications. Comptes Rendus Geosciences 337, 1045-1054.

Boillot, G., Bouysse, P., Lamboy, M., 1971. Morphology, sediments and Quaternary history of the continental shelf between the Straits of Dover and Cape Finisterre. In: Delay, F.M. (Ed.), ICSU/SCOR Working Party 31 Symposium. Cambridge, U.K. The Geology of the East Atlantic Continental Margin, vol. 70. Institute of Geological Sciences, pp. 75-90.

Bonnet, S., Guillocheau, F., Brun, J.-P., Van Den Driessche, J., 2000. Large-scale relief development related to Quaternary tectonic uplift of a Proterozoic- Paleozoic basement: the Armorican Massif, NW France. Journal of Geophysical Research 105, 19273-19288.

Bourillet, J.-F., Turon, J.-L., 2003. Rapport scientifique de la mission MD133/SEDICAR. Les rapports de campagne à la mer. IPEV, Brest. OCE/2003/04, 150 pp.

Bourillet, J.-F., Reynaud, J.-Y., Baltzer, A., Zaragosi, S., 2003. The 'Fleuve Manche': the submarine sedimentary features from the outer shelf to the deep-sea fans. Journal of Quaternary Science 18, 261-282.

Bourillet, J.-F., Menier, D., Gaborit, K., 2005. Architecture des sédiments quaternaires et vallées incises de la marge sud-armoricaine. Abstract Volume 10ème Congrès Français de Sédimentologie. ASF, Paris, Presqu'île de Giens, 11-13 October 2005, p. 42.

Bourillet, J.-F., Zaragosi, S., Mulder, T., 2006. The French Atlantic margin and the deep sea submarine systems. Geo-Marine Letters 26, 311-315.

Bourrouilh, R., Richert, J.-P., Zolnaï, G., 1995. The North Pyrenean Aquitaine basin, France: evolution and hydrocarbons. AAPG Bulletin 79, 831-853.

Bouysse, P., Horn, R., 1971. Etude structurale du plateau continental au large des côtes méridionales de la Bretagne. Cahiers Océanographiques 23, 497-517.

Bouysse, P., Horn, R., Le Gorgeu, J.-P., 1968. Résultats d'une prospection sismique réflexion continue en Bretagne méridionale, entre Penmac'h et Belle-l̂le. Comptes Rendus de l'Académie des Sciences, Paris 267, 568-571.

Bouysse, P., Chateauneuf, J.-J., Ters, M., 1974. Présence d'Yprésien, niveau transgressif et taux de sédimentation flandriens en baie de Vilaine (Bretagne méridionale). Comptes Rendus de l'Académie des Sciences, Paris 279, 1421-1424.

Brault, N., Bourquin, S., Guillocheau, F., Dabard, M.-P., Bonnet, S., Courville, P., EstéouleChoux, J., Stepanoff, F., 2004. Mio-Pliocene to Pleistocene paleotopographic evolution of Brittany (France) from a sequence stratigraphic analysis: relative influence of tectonics and climate. Sedimentary Geology 163, 175-210.

Chantraine, J., Autran, A., Cavelier, C. and others, 1996. Carte géologique de la France à 1/1000000, Revised 2003. Editions BRGM, Orléans.

Chaumillon, E., Proust, J.-N., Menier, D., Weber, N., 2008. Incised-valley morphologies and sedimentary-fills within the inner shelf of the Bay of Biscay (France): a synthesis. Journal of Marine Systems 72, 383-396.

Dalrymple, R.W., Boyd, R., Zaitlin, B.R., et al., 1994. History of research, types and internal organization of incised-valley systems: introduction to the volume. In: Dalrymple, R.W. (Ed.), Incised-valley Systems: Origins and Sedimentary Sequences: SEPM (Society for Sedimentary Geology) Special Publication, vol. 51, pp. 3-10.

Delanoë, Y., 1988. Les grands traits de la structure et de l'évolution géodynamique des dépôts tertiaires du plateau continental sud-armoricain d'après les enregistrements de sismique réflexion. Géologie de la France 1988-1, 79-90.

Delanoë, Y., Pinot, J.-P., 1974. Etude structurale du Tertiaire de la région du Banc Bertin entre Belle-Ile et les Iles de Glénan (Bretagne méridionale). Union des Océanographes de France 6, 59-65.

Delanoë, Y., Lehébel, L., Margerel, J.-P., Pinot, J.-P., 1975. La Baie de Concarneau est un bassin tectonique dans lequel d'épais dépôts du Lutétien supérieur ont été conserves. Comptes Rendus de l'Académie des Sciences 281, 1947-1950.

Delanoë, Y., Margerel, J.-P., Pinot, J.-P., 1976. En Baie de Concarneau, l'Oligocène marin est discordant sur un Eocène ondulé, faillé et érodé, et l'Aquitanien a voilé l'ensemble après une nouvelle pénéplanation. Comptes Rendus de l'Académie des Sciences. Paris 282, 29-32.

Evans, C.D.R., 1990. United Kingdom Offshore Regional Report: the Geology of the Western English Channel and its Western Approaches, British Geological Survey, NERC, HMSO, London.

Evans, C.D.R., Hughes, M.J., 1984. The Neogene succession of the South Western Approaches, Great-Britain. Journal of the Geological Society of London 141 (2), 315-326.

Fulthorpe, C.S., Austin Jr., J.A., Mountain, G.S., 1999. Buried fluvial channels off New Jersey: did sea-level lowstands expose the entire shelf during the Miocene? Geology 27, 203-206.

Fulthorpe, C.S., Austin Jr., J.A., Mountain, G.S., 2000. Morphology and distribution of Miocene slope incisions off New Jersey: are they diagnostic of sequence boundaries? Geology 112, 817-828.

Gély, J.-P., Sztràkos, K., 2000. L'évolution paléogéographique et géodynamique du Bassin aquitain au Paléogène: enregistrement et datation de la tectonique pyrénéenne. Géologie de la France 2000-2, 31-57.
Gély, J.-P., Sztràkos, K., 2001. La tectonique pyrénéenne à l'Oligocène: une phase majeure de déformation en compression méconnue du Bassin aquitain (France). Comptes Rendus de l'Académie des Sciences, Paris 332, 507-512.

Guillocheau, F., Bonnet, S., Bourquin, S., Dabard, M.-P., Outin, J.-M., Thomas, E., 1998. Mise en évidence d'un réseau de paléovallées ennoyées (paléorias) dans le Massif armoricain: une nouvelle interprétation des sables pliocènes armoricains. Comptes Rendus de l'Académie des Sciences, Paris 327, 237-243.

Guillocheau, F., Robin, C., Allemand, P., Bourquin, S., Brault, N., Dromart, G., Friedenberg, R., Garcia, J.-P., Gaulier, J.-M., Gaumet, F., Grosdoy, B., Hanot, F., Le Strat, P. Mettraux, M., Nalpas, T., Prijac, C., Rigollet, C., Serrano, O., Granjean, G., 2000. MesoCenozoic geodynamic evolution of the Paris Basin: 3D stratigraphic constraints. Geodynamica Acta 13, 189-246.

Guillocheau, F., Brault, N., Thomas, E., Barbarand, J., Bonnet, S., Bourquin, S., EstéouleChoux, J., Guennoc, P., Menier, D., Néraudeau, D., Proust, J.-N., Wyns, R., 2003. Histoire géologique du Massif Armoricain depuis 140 Ma (Crétacé-Actuel). Bulletin d'Information des Géologues du Bassin de Paris 40, 13-28.

Hailwood, E.A., Bock, W., Costa, L., Dupeuble, P.A., Müller, C., Schnitker, D., 1979. Chronology and biostratigraphy of northeast Atlantic sediments, DSDP Leg 48. In: Montardet, L., Roberts, D.G., et al. (Eds.), Initial Report of the Deep Sea Drilling Project. Washington, pp. 1119-1141.

Haq, B.U., Hardenbol, J., Vail, P.R., 1987. Chronology of fluctuating sea levels since the Triassic. Science 235, 1156-1167.

Haq, B.U., Hardenbol, J., Vail, P.R., 1988. Mesozoic Cenozoic chronostratigraphy and eustatic cycles. In: Wilgus, C.K., Posamentier, H., Ross, C.K., Kendall, C.G.St.C. (Eds.), Sea-level Changes: An Integrated Approach: Society of Economic Paleontologists and Mineralogists Special Publication, vol. 42, pp. 71-108.

Hilgen, F., Aziz, H.A., Bice, D., Iaccarino, S., Krijgsman, W., Kuiper, K., Montanari, A., Raffi, I., Turco, E., Zachariasse, W.-J., 2005. The Global boundary Stratotype Section and Point (GSSP) of the Tortonian Stage (Upper Miocene) at Monte Dei Corvi. Episodes 28, 6-17.

Huerta, P., Proust, J.-N., Guennoc, P., Thinon, I., 2005. Seismic stratigraphy of the Vendean-Armorican platform of the French Atlantic shelf: new insights into the history of the North Atlantic Ocean. Bulletin de la Société Géologique de France 181, 37-51.

Imbrie, J., Hays, J.D., Martinson, D.G., McIntyre, A., Mix, A.C., Morley, J.J., Pisias, N.G., Prell, W.L., Shackleton, N.J., 1984. The orbital theory of Pleistocene climate: support from a revised chronology of the marine $\delta^{18} \mathrm{O}$ record. In: Berger, A., Imbrie, J., Hays, J. Kukla, G., Saltzman, B. (Eds.), Milankovitch and Climate. Reidel Publishing Company, Dordrecht, pp. 269-305.

John, C.M., Karner, G.D., Mutti, M., 2004. ${ }^{18} \mathrm{O}$ and Marion Plateau backstripping: combining two approaches to constrain late Middle Miocene eustatic amplitude. Geology 32, 829-832.

Kominz, M.A., Miller, K.G., Browning, J.V., 1998. Long-term and short-term global Cenozoic sea-level estimates. Geology 26, 311-314.

Lécuyer, C., Grandjean, P., Paris, F., Robardet, M., Robineau, D., 1996. Deciphering "temperature" and "salinity» from biogenic phosphates: the ${ }^{18} \mathrm{O}$ of coexisting fishes and mammals of the Middle Miocene sea of western France. Paleogeography, Paleoclimatology, Paleoecology 126, 61-74.

Lericolais, G., Auffret, J.-P., Bourillet, J.-F., 2003. The Quaternary Channel River: seismic stratigraphy of its palaeo-valleys and deeps. Journal of Quaternary Science 18 245-260.

Lofi, J., Berné, S., 2008. Evidence for pre-Messinian submarine canyons on the Gulf of Lions slope (Western Mediterranean). Marine and Petroleum Geology 25, 804-817.

Lofthouse, C., Robert, A., 2008. Riffle-pool sequences and meander morphology. Geomorphology 99, 214-223.

Maillard, J., 1982. Rapport de fin de sondage Garlizenn-1 (GEN 1), Mer Celtique permit S.N.E.A.P. (Société National Elf Aquitaine Production. BEPH (Bureau ExplorationProduction des Hydrocarbures) Open file report 14-3527. 20 pp.

Menier, D., 2004. Morphologie et remplissage des vallées fossiles sud-armoricaines: apports de la stratigraphie sismique. Ph.D. Thesis memoir, Université de Bretagne Sud, Mémoires Géosciences Rennes. 110, 202 pp.

Menier, D., Reynaud, J.-Y., Proust, J.-N., Guillocheau, F., Guennoc, P., Bonnet, S., Tessier B., Goubert, E., 2006. Basement control on shaping and infilling of valleys incised at the southern coast of Brittany, France. Society of Economic Paleontologists and Mineralogists. Special Publication 85, 37-55.

Miller, K.G., Mountain, G.S., Browning, J.V., Kominz, M., Sugarman, P.J., Christie-Blick, N., Katz, M.E., Wright, J.D., 1998. Cenozoic global sea level, sequences, and the New Jersey Transect: results from coastal plain and continental slope drilling. Reviews of Geophysics 36, 569-601.

Miller, K.G., Kominz, M., Browning, J.V., Wright, J.D., Mountain, G.S., Katz, M.E. Sugarman, P.J., Cramer, B.S., Christie-Blick, N., Pekar, S.F., 2005. The Phanerozoic record of sea-level change. Science 310, 1293-1298.

Miller, K.G., Browning, J.V., Aubry, M.-P., Wade, B.S., Katz, M.E., Kulpecz, A.A., Wright, J.D., 2008. Eocene-Oligocene global climate and sea-level changes: St. Stephens Quarry, Alabama. Geological Society of America Bulletin 120, 34-53.

Mitchum, J.R., Vail, P.R., Sangree, J.B., 1977. Seismic Stratigraphy and Global Changes of Sea Level, Part 6: Stratigraphic Interpretation of Seismic Reflection Patterns In Depositional Sequences. In: Payton, E. (Ed.), Seismic Stratigraphy - applications to hydrocarbon exploration: American Association of Petroleum Geologist Memoir, vol. 26, pp. 117-133.

Montadert, L., Roberts, D.G., De Charpal, O., Guennoc, P., 1979. Rifting and subsidence of the northern continental margin of the Bay of Biscay. In: Usher, X. (Ed.), Initial Reports of the Deep Sea Drilling Project, Washington, vol. 48, pp. 1025-1060.

Néraudeau, D., 2003. Lithologies, Faunes et Paléogéographies des Dépôts de Type Falun. Bulletin d'Information des Géologues du Bassin de Paris 40, 6-12.

Olivet, J.-L., 1996. La cinématique de la plaque Ibérique. Bulletin des Centres de Recherches, Exploration-Production Elf- Aquitaine 21, 131-195. 
Pigram, C.J., Davies, P.J., Feary, D.A., Symonds, P.A., 1992. Absolute magnitude of the second-order Middle to Late Miocene sea-level fall, Marion Plateau, Northeast Australia. Geology 20, 858-862.

Pinot, J.-P., 1974. Le Précontinent Breton entre Penmac'h, Belle-lle et l'escarpement continental, Etude Géomorphologique, Lannion, Impram. 256 pp.

Posamentier, H.W., 2001. Lowstand alluvial bypass systems: incised vs. unincised. American Association of Petroleum Geologists Bulletin 85, 1771-1793.

Posamentier, H.W., Vail, P.R., 1988. Eustatic controls on clastic deposition II - sequence and systems tract models. In: Wilgus, C.K., Hastings, B.S., Kendall, C.G.St.C., Posamentier, H.W., Ross, C.A., Van Wagoner, J.C. (Eds.), Sea Level Change - An Integrated Approach: Society of Economic Paleontologists and Mineralogists Special Publication, vol. 42, pp. 125-154.

Powell, A.J., 1988. A preliminary investigation into the Neogene dinoflagellate cyst biostratigraphy of the British Southwestern Approaches. Bulletin des Centres de Recherches, Exploration-Production Elf-Aquitaine 12, 277-311.

Praeg, D., Stokerb, M.S., Shannona, P.M., Ceramicolac, S., Hjelstuend, B., Laberge, J.S Mathiesenf, A., 2005. Episodic Cenozoic tectonism and the development of the NW European 'passive' continental margin. Marine and Petroleum Geology 22, 1007-1030.

Preux, R., 1978. Rapport de fin de sondage Penma-1, Loire Maritime permit, S.N.E.A.P. (Société National Elf Aquitaine Production). BEPH (Bureau Exploration-Production des Hydrocarbures) Open File Report 14-3435. 15 pp.

Proust, J-N., Renault, M., Guennoc, P., Thinon, I., 2010. Sedimentary architecture of the Loire drowned valleys of the French Atlantic shelf. Bulletin de la Société Géologique de France 181 (2).

Reynaud, J.-Y., Tessier, B., Proust, J.N., Dalrymple, R., Bourillet, J.-F., De Batist, M. Lericolais, G., Berné, S., Marsset, T., 1999. Architecture and sequence stratigraphy of a late neogene incised valley at the shelf margin, Southern Celtic Sea. Journal of Sedimentary Research 69, 351-364.

Richards, K.S., 1982. Rivers: Form and Process in Alluvial Channels. Methuen, New York $361 \mathrm{pp}$

Stewart, H.A., Davies, J.S., 2007. SW Approaches MESH Survey, R/V Celtic Explore Cruise CE0705, BGS Project 07/06, Operations Report. British Geological Survey Commissioned Report, CR/07/123.

Tcherepanov, E.N., Droxler, A.W., Lapointe, P., Mohn, K., 2008. Carbonate seismic stratigraphy of the Gulf of Papua mixed depositional system: Neogene stratigraphic signature and eustatic control. Basin Research 20, 185-209.
Thinon, I., 1999. Structure profonde de la Marge Nord Gascogne et du Bassin Armoricain. Ph.D. Thesis memoir, Université de Bretagne Occidentale.

Thinon, I., Menier, D., Guennoc, P., Proust, J.-N., Guillocheau, F., Bonnet, S., Le Roy, P., Augris, C., Bourillet, J.-F., Baltzer, A., Tessier, B., Pastol, Y., Garlan, T., Bechennec, F., Le Metour, J., Graviou, P., Alix, A.S., Cornu, S., Loget, N., Scalliet, F., 2008. Carte géologique de la France à $1 / 250000$ de la marge continentale, Lorient, Bretagne Sud. Éditions BRGM-CNRS.

Thomas, E., 1999. Évolution Cénozoïque d'un domaine de socle : le Massif Armoricain. Ph.D. unpublished Thesis memoir, Université de Rennes 1.148 pp.

Vail, P.R., Mitchum, J.R., Todd, R.G., Widmier, J.M., Thompson, S., Sangree, J.B., Bubb, J.N., Hatlelid, W.G., 1977. Seismic stratigraphy and global changes of sea level in depositional sequences. In: Payton, E. (Ed.), Seismic Stratigraphy - Applications to Hydrocarbon Exploration: American Association of Petroleum Geologist Memoir, vol. 26, pp. 49-212.

Vail, P.R, Audemard, F, Bowman, S.A, Eisner, PN, Perez-Cruz, C, 1991. The stratigraphic signatures of tectonics, eustasy and sedimentology - an overview. In: Einsele, G., et al. (Ed.), Cycles and events in stratigraphy. Springer-Verlag, Berlin, pp. 617-659.

Van Vliet-Lanoë, B., Laurent, M., Hallégouët, B., Margerel, J.-P., Chauvel, J.-J., Michel, Y. Moguedet, G., Trautman, F., Vauthier, S., 1998. Le Mio-Pliocène du Massif armoricain. Données nouvelles. Comptes Rendus de l'Académie des Sciences, Paris 326, 333-340.

Vanney, J.R., Horn, R., Martin, G., 1972. La disposition des séquences sédimentaires postmésozoïques sous la partie externe de la plate-forme continentale sud-armoricaine (entre $45^{\circ} 40^{\prime}$ et $46^{\circ} 40^{\prime}$ lat. Nord). Compte Rendus de l'Académie des Sciences 275, 2829-2832.

Waelbroeck, C., Labeyrie, L., Michel, E., Duplessy, J.-C., McManus, J.F., Lambeck, K., Balbon, E., Labracherie, M., 2002. Sea-level and deep water temperature changes derived from benthic foraminifera isotopic records. Quaternary Science Reviews 21, 295-305.

Zachos, J., Pagani, M., Sloan, L., Thomas, E., Billups, K., 2001. Trends, rhythms, and aberrations in global climate 65 Ma to present. Science 292, 686-693.

Ziegler, P.A., 1987. Evolution of the Western Approaches Trough. Tectonophysics 137, 341-346.

Ziegler, P.A., 1990. Collision related intra-plate compression deformations in western and central Europe. Journal of Geodynamics 11, 357-388. 